\title{
Empowering service employees: A case study of banking industry
}

\author{
Hadi Moradi* and Mohammad Reza Fallah
}

Department of Management, Farabi Pardis, University of Tehran, Qom, Iran

\begin{tabular}{|c|c|}
\hline CHRON I C LE & A B S TRACT \\
\hline $\begin{array}{l}\text { Article history: } \\
\text { Received January } 14,2014 \\
\text { Accepted } 10 \text { June } 2014 \\
\text { Available online } \\
\text { June } 182014 \\
\text { Keywords: } \\
\text { Empowering employees } \\
\text { Individual factors } \\
\text { Job related factors } \\
\text { Organizational factors }\end{array}$ & $\begin{array}{l}\text { This paper presents an empirical investigation to study the effects of different factors } \\
\text { influencing empowering employees in banking industry. The proposed study designs a } \\
\text { questionnaire in Likert scale, which contains three components of individual, job related and } \\
\text { organizational related factors. Cronbach alpha is calculated as } 0.88 \text {, which is well above the } \\
\text { minimum acceptable level of } 0.7 \text {. Using stepwise regression analysis, the study has detected a } \\
\text { positive and meaningful relationship between employee performance and three individual, job } \\
\text { related and organizational issues. In addition, the implementation of Freedman test indicates } \\
\text { that organizational based factors were number one priority on employee performance followed } \\
\text { by job related factors and individual factors. }\end{array}$ \\
\hline
\end{tabular}

(C) 2014 Growing Science Ltd. All rights reserved.

\section{Introduction}

During the past few decades, businesses have emerged to adopt an empowerment approach to service industry including banking businesses. Empowering employees has gained almost a "born again" religious fervor (Bowen \& Lawler III, 2006; Scott \& Jaffe, 1991; Kinlaw, 1995). Fulford and Enz (1995) explored the impacts of empowerment on employee perceptions of satisfaction, performance, loyalty, level of service delivery, and concern for others. They presented a conceptualization of empowerment to examine multiple dimensions of the construct, including meaning, self-efficacy, self-determination, and personal control. They reported that degree of perceived empowerment could explain some of the variation in employee attitudes. In their survey, the empowerment dimension of meaning was detected to gain the biggest impact on perceived loyalty, concern for others, and satisfaction. The survey also concluded that empowerment differs by employment status, but not by position in the organization. The term empowerment has become a common usage but it is open not only to vague interpretation but to misuse (Burdett, 1991; Kanter, 1985). What is required is not only a common model of understanding (a model); but insight into the nature of power in the organization and necessary supervisory and managerial learning in an empowered environment.

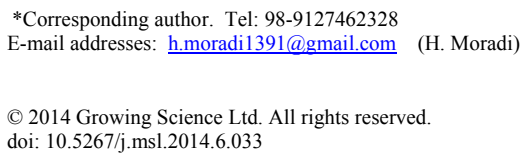


Conger and Kanungo (1988) addressed some shortcomings by providing an analytical treatment of the construct and by combining the diverse methods to empowerment detected in both the management and psychology literatures. They also identified certain antecedent conditions of powerlessness and practices, which were hypothesized to empower subordinates. According to Geroy et al. (1998), employee empowerment is one of the key management concepts of our time. Many organizations look for unleashing employee potential by empowering them. However, mainstream empowerment programs may not reflect the unique problems encountered by disadvantaged employees, namely, people with disabilities, women, and ethnic minorities. Therefore, the programs may fail to offer solutions, which can both facilitate the resolution of the problems and enable firms to maximize the benefits of empowerment initiatives (Echiejile, 1994). Morley (1995) explored the concept of empowerment and raises questions about the possible reason for its rise to dominance as a current discourse in the United Kingdom public services. Nykodym et al. (1994) investigated the development of employee empowerment from its beginnings as American academic research to its successful adaptation by the Japanese management and later US management.

\section{The proposed study}

This paper presents an empirical investigation to study the effects of different factors influencing empowering employees in banking industry. The proposed study designs a questionnaire in Likert scale, which contains three components of individual, job related and organizational related factors. Fig. 1 demonstrates the proposed study of this paper,

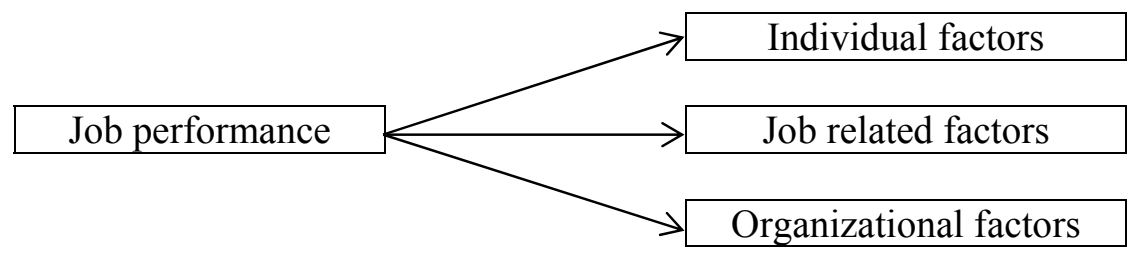

Fig. 1. The proposed study

Cronbach alpha is calculated as 0.88 , which is well above the minimum acceptable level of 0.7 . Kolmogorov-Smirnov test for three individual, job related, organizational factors is calculated as 0.401 with Sig. $=0.997$, which means all components are normally distributed. Table 1 shows details of Pearson correlation ratios among different pairs of investigation.

Table 1

The results of Pearson correlations

\begin{tabular}{cccccc}
\hline Variable & & Job related & Individual factors & Organizational factors & Job performance \\
\hline \multirow{2}{*}{ Job related } & $\mathrm{r}$ & 1.00 & 0.438 & 0.562 & 0.49 \\
& $\mathrm{Sig}$. & - & 0.000 & 0.000 & 0.001 \\
\hline \multirow{2}{*}{ Individual factors } & $\mathrm{r}$ & 0.365 & 1 & 0.862 & 0.905 \\
& $\mathrm{Sig}$. & 0.000 & - & 0 & 0.000 \\
\hline \multirow{2}{*}{ Organizational factors } & $\mathrm{r}$ & 0.562 & 0.861 & - & 0.974 \\
& $\mathrm{Sig}$. & 0.000 & 0 & 0.974 & 0.000 \\
\hline \multirow{2}{*}{ Job performance } & $\mathrm{r}$ & 0.49 & 0.905 & 0.000 & 1 \\
& $\mathrm{Sig}$ & 0.000 & 0.000 & & - \\
\hline
\end{tabular}

As we can observe from the results of Table 1, there are strong and positive relationships between various components of the survey. We also use stepwise linear regression model to study the relationship between employees' performance and three mentioned factors as follows,

Employee performance $=\beta_{0}+\beta_{1}$ Job related $+\beta_{2}$ Individual $+\beta_{3}$ Organizational $+\varepsilon$ 
Table 2 shows details of the regression analysis. In addition, Table 3 demonstrates the results of ANOVA test.

\section{Table 2}

The results of regression analysis

\begin{tabular}{ccccccc}
\hline & \multicolumn{2}{c}{ Non-standard coefficients } & Standard coefficients & & \\
\hline & $\mathrm{B}$ & Std. Error & $\beta$ & t-value & Sig. \\
\hline Intercept & .0133 & .063 & - & 3.202 & 0.00 \\
Organizational & .305 & .023 & .575 & 13.025 & 0.00 \\
Job related & .218 & .023 & .310 & 6.098 & 0.00 \\
Individual & .00214 & .014 & 0.41 & 4.153 & 0.00 \\
\hline
\end{tabular}

Table 3

The summary of ANNOVA test

\begin{tabular}{cccccc}
\hline & Sum of squares & df & Mean Squares & F-value & Sig. \\
\hline Regression & 985.589 & 1 & 985.589 & 48.816 & 0.001 \\
Residual & 4825.399 & 239 & 20.19 & & \\
\hline Total & 5810.988 & 240 & & & \\
\hline
\end{tabular}

As we can observe from the ANNOVA test, F-value is significant and there are some linear relationships between independent variables and dependent variable. The results of Table 2 show that organizational factors maintain the highest impact on employee performance. We have also performed Freedman test to rank the effects of three variables and the result indicates that organizational based factors are number one priority on employee performance $(r=4.31)$ followed by job related factors $(\mathrm{r}=2.84)$ and individual factors $(\mathrm{r}=1.65)$.

\section{Conclusion}

In this paper, we have presented an empirical investigation to study the effects of three individual, job related and organizational factors on employee performance. The study has implemented Pearson correlation and realized that job related factor has positive and meaningful relationship with individual $(\mathrm{r}=0.438)$, job related $(\mathrm{r}=0.490)$ and organizational factors $(\mathrm{r}=0.562)$. The strongest relationship was between employee performance and organizational factor $(r=0.974)$. In addition, the implementation of Freedman test has indicated that organizational based factors were number one priority on employee performance $(r=4.31)$ followed by job related factors $(r=2.84)$ and individual factors $(\mathrm{r}=1.65)$.

\section{References}

Bowen, D. E., \& Lawler III, E. E. (2006). The empowerment of service workers.Managing innovation and change, 155-69.

Burdett, J. O. (1991). What is empowerment anyway?. Journal of European Industrial Training, 15(6).

Conger, J. A., \& Kanungo, R. N. (1988). The empowerment process: Integrating theory and practice. Academy of management review, 13(3), 471-482.

Fulford, M. D., \& Enz, C. A. (1995). The impact of empowerment on service employees. Journal of Managerial Issues, 7(2), 161-175.

Echiejile, I. (1994). Empowering disadvantaged employees. Empowerment in Organizations, 2(1), 31-37.

Geroy, G. D., Wright, P. C., \& Anderson, J. (1998). Strategic performance empowerment model. Empowerment in Organizations, 6(2), 57-65. 
Kanter, R. M. (1985). Dilemmas of managing participation. Readings in Human Resource Management. New York, London, 196-226.

Kinlaw, D. C. (1995). The practice of empowerment: making the most of human competence. Gower Publishing, Ltd.

Morley, L. (1995). Theorizing empowerment in the UK public services. Empowerment in Organizations, 3(3), 35-41.

Nykodym, N., Simonetti, J. L., Nielsen, W. R., \& Welling, B. (1994). Employee empowerment. Empowerment in Organizations, 2(3), 45-55.

Scott, C., \& Jaffe, D. (1991). Empowerment building a committed workforce. Crisp Learning. 